\title{
CULTO, DEVOÇÃO E SANTIDADE: UM ESTUDO BIBLIOGRÁFICO SOBRE O PROCESSO SANTORAL NA RELIGIOSIDADE CRISTÃ
}

\section{WORSHIP, DEVOTION AND HOLINESS: A BIBLIOGRAPHICAL STUDY ON SANCTORAL PROCESS IN CHRISTIAN RELIGIOSITY}

\author{
Yleana do Socorro dos SANTOS LIMA*
}

\begin{abstract}
RESUMO: O presente artigo apresenta a priori, a religião cristã em suas diversas matizes, sendo que o catolicismo favorece a ligação entre a Igreja Católica e o culto a santos católicos e populares. Nesse contexto o trabalho visa mostrar a religiosidade como forma de sustentação dos valores cristãos e doutrinários do catolicismo e a rigorosidade aos assuntos dados sobre a santidade. $\mathrm{O}$ objetivo deste trabalho é apresentar o culto aos santos como um dos principais elementos do Cristianismo, sendo que tradicionalmente a devoção a centenas de divindades do panteão católico pode ser entendida como um dos pilares desta religião, sobretudo por seus aspectos doutrinários e identitários. Para esse contexto foi realizado um estudo bibliográfico sobre alguns autores como: André Vauchez (1987), Bourdieu (1998, Durkheim (1982, Lourdes dos Santos (2000), Machado (1995), Romualdo Rodrigo (1988) e dentre outros.
\end{abstract}

Palavras-Chave: Culto. Devoção. Santos. Santidade. Religião

\begin{abstract}
This paper presents firstly the Christian religion in its several nuances, in which the Catholicism favors the connection between the Catholic Church and the worship to Catholic and popular saints. In this context, the work aims at showing the religiosity as a way of sustaining Christian and doctrinaire values from the Catholicism and the rigorousness in the issues of holiness. The objective of this work is to present the worship to saints as one of the main elements of the Christianity, since the devotion to hundreds of divinities from the Catholic pantheon is traditionally understood as one of the pillars of this religion, especially for its doctrinaire and identity aspects. For this context, a bibliographical study was accomplished, and it has as basis some authors, such as André Vauchez (1987), Bourdieu (1998, Durkheim (1982), Lourdes dos Santos (2000), Machado (1995), Romualdo Rodrigo (1988) among others.
\end{abstract}

Keywords: Worship. Devotion. Santos. Holiness. Religion.

\section{Introdução}

$\mathrm{O}$ atual pluralismo religioso em várias partes do mundo, com diferentes intensidades e matizes, tem suscitado inquietações e investigações em diversos campos do saber. A religião cristã surgiu na região da atual Palestina no Século I. Essa região

\footnotetext{
* Mestranda do Programa de Pós Graduação em Linguagens e Saberes na Amazônia, Campus Universitário de Bragança - Universidade Federal do Pará. E-mail: ylelima@ hotmail.com.
} 
estava sob domínio do Império Romano neste período. Espalhou-se rapidamente pelos quatro cantos do mundo, se transformando atualmente na religião mais difundida.

O Cristianismo é uma religião monoteísta centrada nos ensinamentos de Jesus, tais como são apresentados no Novo testamento. A religião cristã possui três vertentes principais: o Catolicismo, a Ortodoxia Oriental (separada do catolicismo em 1054 após o Grande Cisma do Oriente) e o Protestantismo (que surgiu durante a Reforma Protestante do século XVI).

Segundo Wilges (1982) o Cristianismo é católico, isto é, universal. Nesse caso, considera-se uma religião para todos os povos, para todas as raças e culturas. Não é uma religião local, regional ou nacional.

Partindo desses pressupostos, a Igreja Católica tem a convicção de que ela foi fundada por Jesus Cristo, a quem ela prega, conserva e vive em seus sacramentos e ministérios. Nela tem-se a convicção da totalidade dos meios de salvação.

O Catolicismo é um termo usado geralmente para uma experiência específica do cristianismo compartilhada por cristãos que vivem em comunhão com a Igreja de Roma. Um outro aspecto importante é com relação ao culto de santos, os protestantes não aceitam os santos como intercessores. Jesus Cristo é o único mediador. Para os católicos Jesus Cristo também é o único mediador (1 Tm 2,5), que não exclui a mediação dos santos. A Igreja Católica os venera como veneramos pessoas queridas (mas não os adora, isto se deve a Deus). Na doutrina cristã se prega a adoração de um único Deus. Nesse sentido os santos católicos surgem não como deuses, mas como exemplos de vida, exemplos estes associados por valores cristãos como a preocupação com o bemestar do próximo e a despreocupação com as riquezas materiais.

Vale destacar, o rigor com que a Igreja Católica determina a santidade de uma pessoa: examina-se primeiro sua vida para verificar se ela está pautada pelos valores cristãos de modo exemplar. Em seguida, comprova-se a ocorrência de um milagre atribuído a pessoa, após estas etapas, a Igreja pode atribuir à pessoa o título de beato (SANTOS, 2000).

Se for comprovada a ocorrência de mais de um milagre atribuído ao beato, este pode ser enfim declarado santo pela Igreja. A rigorosidade deste processo tem por objetivo certificar-se da real santidade do candidato a santo, ou seja, verificar se ele está realmente unido a Deus.

São Benedito é um destes santos cultuados pelo povo e declarado santo pela Igreja católica com os seus 27 milagres contabilizados pelo Tribunal eclesiástico 
(BESEN, 2004). A festa em homenagem ao santo preto ocorre em várias regiões do Brasil e em Bragança do Pará seu culto traduz uma intensa manifestação da religiosidade popular. Neste momento o conceito de hibridismo cultural contribui enquanto referência para os estudos acerca da religiosidade católica.

O autor Burke em seu estudo sobre hibridismo cultural enfatiza que os contatos entre culturas atingem a todos os povos desde tempos muito remotos e o fazem de modo sucessivo e constante.

Devemos ver as formas hibrídas como o resultado de um único encontro, quer encontros múltiplos e não como o resultado de um único encontro, quer encontros sucessivos adicionem novos elementos à mistura, quer reforcem os antigos elementos (BURKE, 2003, p. 31).

Desde seu processo de formação, o cristianismo e posteriormente o catolicismo, é caracterizado por ser uma religião híbrida, isto é, composta e construída em um momento específico. O hibridismo cultural possui um sentido de mostrar que o sujeito ao ter contato com outra cultura, sejam as crenças, costumes, tradição, ou mesmo música, dança e dentre outros, une as experiências compartilhadas em um determinado espaço na sociedade, favorecendo os valores dos grupos sociais e da comunidade.

O símbolo, um dos grandes aportes do dinamismo social da religião, torna esta forte e explica o pertencimento vivenciado pelo fiel. Na religião e nas práticas de culto a santos, o fiel recupera, por meio deles, seus desejos reprimidos, o que alimenta de certa forma, a esperança por dias melhores.

Há uma riqueza de símbolos que delimitam não só o universo específico da religiosidade e do culto a santos, mas também toda a realidade social. Movimenta-se numa dança de símbolos que exige um cuidado quanto ao modo de apresentá-los e interpretá-los. Vale, nesse sentido, lembrar os "milagres de São Benedito" que tanto a Instituição religiosa quanto o povo consideram o símbolo da cura, da graça e da benção como fatos reais.

Faz-se mister, assim partilharmos a noção de símbolo, porque embora pareça simples, é bastante significativa;

Não se trata do símbolo no sentido da deliberação do princípio de realidade (o como se, mas de um código, pela mediação do mito, do conto, da parábola, da metáfora, do rito, da festa, um código performativo como dizem os lingüistas, que convida a práxis. Não devemos esquecer que a linguagem religiosa só pode ser simbólica. Numa cultura que se impõe cada vez mais o símbolo lógico-matemático a serviço de um processo mercantilizado, perdeuse grande parte do símbolo como linguagem existencial (HOUTART, 2003 p. 43). 
O convite a práxis, conforme sugerido acima decorre da noção maior de que o símbolo-realidade aberta que é - implica relação, supõe significação intersubjetiva. A questão simbólica não é demarcada pelo caminho da linguagem conceitual, pois as imagens que brotam do seu interior não são vazias, indecifráveis ou complicadas. Caso fosse assim, o mundo das coisas religiosas, mundo prenhe de imaginação, não deixaria livres as criações do espírito;

Assim a religião, como as práticas religiosas não seria o que é se não concedesse um lugar às livres combinações do pensamento e da atividade, ao jogo, à arte, a tudo o que diverte o espírito fatigado com o que há de sujeição excessiva no trabalho cotidiano. (DURKHEIM, 1996, p. 416)

O homem não vê as coisas como fatos objetivos, mas como valores; a realidade aparece impregnada de mistérios e sentidos ocultos. Olhando para um dos símbolos centrais do mundo cristão, por exemplo, a cruz, diríamos que ela carrega um significado de fundamental importância para a vida de boa parte dos fiéis dessa religião.

Para tais adeptos, o referido símbolo parece trazer à tona "coisas ausentes" ou impossíveis de serem percebidas concretamente. Nessa perspectiva, tais coisas ausentes acabam por se transformar nos próprios assuntos de tanto que se quer falar, como se tivessem uma concretude à parte do objeto.

O símbolo, portanto, começa a desenvolver sua função, ou seja, evocar, através da relação "natural", algo ausente ou não mais possível de ser percebido sensualmente. "Ele traz, assim, sentido novo à realidade histórica e pode ser interpretado em várias direções: pode provocar dominação, conformismo, resistência e transformação". (Cf. BOURDIEU, 1998, p. 11). Não raro, a sociedade atribui sacralidade a certos fenômenos ou acontecimentos em momentos de grandes efervescências culturais, como aqueles períodos de crises históricas, de choques culturais violentos.

Em circunstâncias assim, a busca por novas modalidades de interação social se torna mais frequente, mais ativa, destacando-se a interdependência, a solidariedade e a religiosidade (sacralidade patente ou camuflada). Lynn Hunt (1990, p. 27-28), tratando da relação sociedade e sagrado, reflete sobre tal questão a partir da Revolução Francesa, deixando claro que,

(...) apesar de ostensivamente política em sua origem, funcionou nas linhas e assumiu muitos aspectos de uma revolução religiosa, a revolução foi tocada por uma qualidade messiânica: pelo desejo revolucionário (querer) de levar a boa nova aos homens de todos os lugares.

Toda sociedade exige, para se instaurar e se perpetuar, referência a uma ordem legitimadora de sua existência. Para Durkheim (Cf. BOUDON; BOURRICAUD, 1993: 
490), a sociedade como totalidade antecipa-se ao indivíduo, mas ela é, sobretudo, fenômeno de comunicação tornada possível por meio das crenças coletivas. Nesse sentido, na ótica sociológica durkheimiana, a função da religião seria conservar a unidade e a integração social. Isso porque, nos seus estudos, as coisas sagradas são símbolos constitutivos da vida social, o que revela o entendimento de que a religião, mesmo na modernidade, constitui elemento central da vida da sociedade.

Segundo Durkheim, trata-se de uma coisa eminentemente social. As representações religiosas são coletivas e exprimem realidades coletivas; os ritos, maneiras de agir, surgem, exclusivamente, no interior de grupos coordenados e se destinam a suscitar, manter ou refazer alguns estados mentais dos grupos. Então, se as categorias sociais têm origem religiosa, devem participar da natureza comum a todos os fatos religiosos: devem ser coisas sociais, produtos do pensamento coletivo. (DURKHEIM, 1996, p. 16).

Observa-se, portanto, que Durkheim busca a integração da religião numa teoria da sociedade, mas não identifica a sociedade com Deus. Ele a coloca na esfera dos símbolos e crenças, ou seja, considera religião um fato simbolicamente ligado à sociedade.

Na perspectiva de mudança, não convém deixar de lado a questão das raízes sociais da religiosidade. Os sistemas de crenças não são de modo algum acidentais; surgem em respostas as necessidades sociais. Em qualquer forma dada ou em qualquer momento, uma religiosidade particular atuará como baluarte de certo tipo de relação de produção ou como instrumento para transformá-la. Isso ocorre pelo fato de estar integrada ao sistema social e de os indivíduos que a vivenciam refletirem tão somente necessidades advindas da condição de interdependência, reflexo, de um modo de vida social.

Ao mesmo tempo em que as práticas sociais se tornaram uma "estrutura estruturada", também levou consigo um "aspecto estruturante" (BOURDIEU, 2001), definindo formas de elaboração e discursos articulados a um conjunto de práticas, sancionados por uma hierarquia que passou a determinar o que era ser católico (CERTEAU, 1994).

De forma geral, as expressões de religiosidade, assim como outros aspectos da vida social, fazem parte do sistema de vida de um grupo que, no campo religioso, envolve além da crença, um conjunto de práticas comportamentais. Nesse sentido, 
(...) não se trata de elaborar um modelo geral para derramar neste molde o conjunto de práticas, mas ao contrário, de especificar esquemas operacionais e verificar se existem entre eles, categorias comuns e, se em tais categorias, é possível explicar o conjunto de práticas (IDEM, 1994, p. 20-21).

Subtende-se que a religiosidade católica seja as manifestações que envolvem as crenças e práticas ligadas ao catolicismo, que tem como ponto crucial o culto aos santos reconhecidos ou não pela Igreja.

É o contato com o transcendente que, apesar de estar fortemente ligado ao institucional, ao mesmo tempo distancia-se dele, num processo de apropriação que muitas vezes marca um conflito simbólico na adoção de crenças e práticas não sancionadas, nas quais o devoto acredita estar vivenciando sua religião, sem a preocupação dela estar ou não sancionada pela Instituição.

\section{Práticas de culto e devoção a santos}

No primeiro século da era cristã, os cultuados como santos foram os mártires, cujo nome foi dado por representarem testemunhos de adesão a fé cristã. Com o passar do tempo, o martírio passou a ser caracterizado por uma morte violenta (motivo de doença grave ou homicídio) (MACHADO, 1995).

Nesse aspecto o martírio tinha como símbolo submissão ao Cristo no imaginário cristão da época, tendo em vista que santidade e martírio tinham basicamente o mesmo significado, isto é, era preciso se sacrificar, morrer por Cristo e como Cristo morrer para consagrar os homens.

O culto aos santos está presente desde a constituição da hierarquia cristã e, sua consequente necessidade em firmar valores morais, faz-se uso de modelos exemplares que traduziriam sua visão de mundo.

\footnotetext{
Santidade é um termo aplicado pelas Sagradas Escrituras para designar a qualidade do que é essencialmente divino. Do hebraico, santo e santidade significam separado, segregado e são termos que se relacionam com Deus, "separado do profano, o Santo dos Santos, o único absolutamente santo" (MACHADO, 1995, p. 13).
}

No livro de Gênesis (2, 2-3), os sacerdotes indicaram bem essa diversidade afirmando que Deus abençoou e santificou o sétimo dia, porque foi nesse dia que Deus descansou de todo o seu trabalho como "Criador", evidenciando o entendimento dicotômico de sagrado e profano pois, seis dias são profanos, de trabalho, e um sagrado de exaltação a Deus.

Nesse contexto, o termo santo era utilizado para designar o que está próximo de Deus, ou lhe é consagrado, quer se tratasse de lugares, como o Templo de Jerusalém, 
como também de pessoas, especialmente os sacerdotes que se dedicavam inteiramente ao serviço de Javé, por isso são considerados "Testemunhas do Inefável, cabendo-lhes a tarefa de propagar a pureza ritual, sem a qual não se obteria os efeitos do culto, conforme indicado na "Lei de Santidade" do Levítico (17-26). No sentido de coletividade, os hebreus se reconheciam como "povo santo" por terem sido escolhidos por Deus para sua Revelação e, por isso, eles entendiam que não podiam mais viver como os demais povos, ainda desconsagrados.

No Novo Testamento, o ideal de santidade se realizou plenamente através de Jesus Cristo, cujo mistério está ligado a Santíssima Trindade, em que o filho reflete integralmente o esplendor do Pai. Nesta perspectiva, a santidade consiste, pois em amar como amou o próprio Cristo, enquanto o "novo povo santo" é representado agora pela incorporação de todos os batizados, judeus e pagãos.

Com os profetas, algumas vezes identificados como santos, a idéia de santidade adquiriu um sentido voltado para a moralidade e para o espiritual, afirma o teólogo francês Douillet (1960), em que os santos realizam de maneira excelente aquilo que todo o cristão deveria querer ser, se tivesse consciência de sua vocação.

No sentido ontológico, segundo Rodrigo (1988), não há diferença entre a santidade do cristão medíocre e a santidade daquele que pratica as virtudes em grau heroico e por isso está intimamente unido a Cristo, porque a santidade não é outra coisa senão a comunhão com Deus.

Assim, raciocina ele quanto mais íntima for essa união, maior será o grau de santidade da pessoa. Os santos oficiais são os gigantes da santidade porque os cristãos comuns que não alcançaram ainda uma última união com Cristo são santos pequenos, não cresceram suficientemente, não ultrapassaram os limites da mediocridade.

Para Baroja (1995), no entanto, o conceito de santidade é muito mais amplo e relativo, podendo ser aplicado de maneiras distintas, uma vez que personagens considerados santos em determinadas sociedades, podem não ser aceitos em outros locais.

Ou seja, pois os referenciais para seu reconhecimento, ultrapassando a esfera religiosa, reportam-se ao cultural, ao político, de cada época e local, num processo constante, ainda que lento, de mutação. Nesta mesma concepção, Dominique Julia (1976, p. 106) afirma que,

(...) as mudanças religiosas só se explicam se admitirmos que as transformações sociais produzem nos fiéis modificações de idéias e desejos que os obrigam a alterar partes de seu sistema religioso. Há uma continuidade 
de ida e volta uma infinidade de reações entre os fenômenos religiosos, a posição dos indivíduos no interior da sociedade e os sentimentos religiosos individuais.

Dessa forma perseguindo o pensamento durkheiminiano ${ }^{1}$ de que a religião é a condição de vida em sociedade, em todas as épocas e que não há grupos sociais que não sintam necessidade de manter e reafirmar, a intervalos regulares, os sentimentos e as ideias coletivas que fazem sua unidade e, sobretudo, sua identidade, Servilio Conti (1997, p. 516) indica que

(...) em cada época da história da igreja surgiram, providencialmente, modelos novos de santidade conforme as necessidades dos tempos, mas que também, pode-se encontrar modelos de santidades que se repetem, em diferentes momentos, denotando a permanência ou a retomada de alguns perfis $(\ldots)$

O historiador André Vauchez (1987), compartilhando deste parecer, observa que o conceito de santidade encontra-se na maior parte das religiões, com um significado ambivalente, mas evocando sempre, uma ruptura da condição humana, assim como uma possibilidade de estabelecer uma relação com o divino susceptível de efeitos purificadores.

Nessa linha, indica o autor, na antiguidade greco-romana, esse conceito era aplicado à qualidade das divindades celestes e de alguns poucos homens, considerados semi-deuses, por terem sido agraciados com poderes sobrenaturais, como a imortalidade, a magia e o privilégio de viverem nos campos Elíseos ou entre os deuses do Monte Olimpo.

Esta santidade supracitada jamais qualificava um homem vivo, ainda que alguns exemplos de seres excepcionais, como o herói Hércules, pudessem ascender à esfera de perfeição e da imortalidade, remetendo-os, de certa forma, à excepcionalidade e, por isso, ao mundo dos deuses. Já para a tradição oriental, Vauchez aponta que

\footnotetext{
A santidade também era tida como um elo entre o plano natural e um patamar superior, alcançado por meio de uma purificação espiritual que afastava o homem das coisas do mundo, como os pensamentos maculados e os prazeres terrenos do corpo, aproximando-o do Divino, através da sabedoria, virtudes e meditações e sacrifícios, como o jejum e o isolamento (1987, p. 289).
}

Com a difusão do cristianismo, a noção de santidade se tornou um elemento de grande importância para a compreensão de certas civilizações e épocas. Os evangelistas, sobretudo João (1, 1-2), sublinharam com insistência a originalidade do Cristo, e o seu apelo universal à santidade, dirigido por Deus a todas as criaturas, mesmo porque com sua palavra e ação, Jesus teria transformado as relações dos homens com Deus e dos homens entre si. 
Mais tarde, essa situação foi evidenciada por Paulo de Tarso, ex-fariseu e apóstolo dos gentios, na Primeira Carta aos Coríntios $(1,2)$, quando ele aponta para todos os bens e poderes de que são acumulados já na terra "aqueles que foram santificados em Cristo Jesus, chamados a ser santos".

Assim, no contexto dos primeiros tempos da Igreja, foram considerados santos e venerados pela comunidade de fiéis, a Virgem ${ }^{2}$, os apóstolos e os mártires ${ }^{3}$ - os testemunhos privilegiados de Cristo. Dessa forma, a devoção aos mártires emergia espontaneamente como fruto do entusiasmo e de veneração dos fiéis que consideravam heróis da cristandade perseguida ${ }^{4}$.

Já o consentimento e a oficialização do culto cabia às autoridades eclesiais, por isso, desde cedo, as Igrejas particulares se preocupavam em recolher as Atas dos Mártires, com o nome, data e tipo de martírio e do sepultamento, para que a memória não se perdesse com o tempo. Daí surgiu os martiriólogios e os calendários para a celebração do aniversário do martírio, com destaque para o Martiriológio Romano ${ }^{5}$.

Romualdo Rodrigo (1988) aponta que na época de Constantino (324-337), o culto aos mártires alcançou um grande esplendor, marcando sua expansão no mesmo compasso da expansão da Igreja. Peregrinações eram organizadas às catacumbas e se oferecia em sua honra a Eucaristia.

Com o tempo, muitos cultos deixaram de ser locais e se estenderam por todo Mediterrâneo. Rodrigo (1988) adverte, no entanto que, apesar das provas dos martírios, não se pode falar em um processo canônico como se entende hoje, especialmente ao referente às provas dos milagres. Exigia-se apenas um exame crítico das atas do martírio e o juízo do bispo da Igreja local de quem dependia a autorização para o culto. Era fundamental, antes desta permissão, constar dessa análise se o agressor havia inferido a morte por ódio à fé e se o mártir havia aceitado voluntariamente por amor a Cristo.

De qualquer forma, para ser merecedor da santidade, um homem deveria "agir como um santo, imitando a Deus e mantendo-se puro dos pecados" (EFÉSIOS 5, 1-20).

Por isso, no processo de santificação dos mortos, afirma Vauchez (1987), faz-se necessário a sacralização de suas vidas. Remetendo-se, sobretudo, às práticas medievais, o autor focaliza o momento em que a Igreja construía a santidade de eclesiásticos e monarcas, canonizando-os por seus "grandes serviços" àquela instituição, especialmente os fundadores de santuários e mosteiros, ofuscando a popularidade anterior dos consagrados à ascese. Desta forma, enfatiza a historiadora Maria de Lourdes dos SANTOS, 
o nobre, potencialmente santo, deveria congregar as origens e as qualidades do chefe cristão e ter governado seus domínios como bom súdito da Igreja. Nesse caso, a santidade era concedida como uma forma especial de reconhecimento aos préstimos que a nobreza prestava à fé católica (2000, p. $35)$.

A partir do século XI e da Reforma Gregoriana, o papado reagiu contra todas as formas de sacralização do poder laico, reservando-se o direito de santificação de qualquer servo de Deus e de autorizar que lhe fosse instituído um culto litúrgico. Em pouco tempo, firmaram-se os processos de canonização, fundamentados na vida virtuosa e nos milagres atribuídos a eles, numa época em que os dogmas fundamentais do Cristianismo eram atacados por muitas práticas heréticas e por outros grupos religiosos, como os cátaros ${ }^{6}$, por exemplo, que procuravam reafirmar o seu vigor ascético.

No século seguinte constituiu-se a reserva pontifícia do direito de canonização, pois, até então, o culto popular era ratificado pelo bispo, o que equivalia à canonização. Doravante só o papa tinha o poder de se pronunciar, em última instância sobre a santidade de um servo de Deus e de autorizar seu culto litúrgico. A sanctione de Romatinha por alvo, segundo Douillet (1960), garantir maior prestígio das relíquias, na diocese do santo, e assegurar nas dioceses vizinhas, a autenticidade do novo santo, pois a fantasia que frequientemente inspirava as canonizações locais tinha diminuído o seu crédito.

Tempos depois, se firmaram as investigações ordenadas por Roma sobre a vida, as virtudes e os milagres dos candidatos a santos, constituindo-se em verdadeiros instrumentos de seleção dos sanctus, tema que será tratado, com maior profundidade mais adiante. No entanto, pode-se ressaltar, desde já, que a afirmação, dessas novas estruturas, atestava mais do que a centralização da hierarquia eclesiástica e a subordinação de todos a ela, promoveram um novo entendimento no significado de santidade uma vez que sublinhavam a transcendência da natureza divina do santo.

Nessa perspectiva, o teólogo Ricardo Willy Rieth defende que, tal característica pressupunha uma identificação profunda com a vida de fé dos santos, pois "seu exemplo deveria animar o homem simples a suportar sofrimentos semelhantes aos que eles, os santos, haviam suportado" (RIETH, 2000, p. 854).

Assim, a devoção aos santos e a Maria ${ }^{7}$ seriam exemplos de paganismo e como tal deveriam ser prontamente rechaçados pelos protestantes. Para eles a devoção santoral e as expressões de fé populares eram, marcadamente, sinais de atraso, 
superstição e ignorância religiosa. Por isso, esclarece Ricardo Rieth, toda piedade relacionada a anjos e santos, como adoração, jejum em sua honra, celebração de festas e missas, sacrifícios, instituição de altares e cultos, busca de auxílio, era considerada idolatria e retirava a honra de Deus, enquanto a prática da invocação de santos afastava Cristo, o único mediador.

Como reação a essas críticas, a Igreja Católica procurou aumentar o seu controle sobre as devoções populares, afirmando que uma nova santidade não poderia ser ratificada se já fosse de culto público. Desse modo, foi subtraído oficialmente do povo católico, o poder de criar santos, embora oficiosamente nunca tenha deixado de fazê-lo.

Dessa forma, a partir do século XVI, a santidade oficial desenvolveu-se, proeminentemente, no âmbito dos institutos de purificação, constituindo a expressão de uma religião puramente espiritual, na qual os santos encarnavam certo número de virtudes, verdadeiras apologias para os fiéis.

Nesse sentido, Douillet (1960) aponta que os biógrafos deixaram-se levar, quase sempre, ou pelo fervor que os incitava a não omitir coisa alguma que poderia talvez aumentar a glória do seu herói ou pelo gosto de seus leitores que reclamavam histórias maravilhosas, o que para, Vauchez (1987) significa o ato de sacralizar a vida daqueles tidos como santos, confirmando, de certa forma, a máxima que afirma que a santidade é algo que se concretiza visivelmente no céu, mas que é construída somente na terra. Visto assim, a santidade simboliza o diálogo entre a graça e o esforço, entre Deus que santifica e o homem que se reveste de fé.

Nos séculos seguintes, cresceu entre os católicos, o desejo de terem nos altares, imagens mais familiares e com as quais havia laços identitários. O modelo de santidade que foi sendo reelaborado enfatiza a historiadora Maria Clara Machado em que representou, portanto, um retorno à heterogeneidade. Nele foram canonizados missionários, místicos, visionários e taumaturgos, os fazedores de milagres, ou melhor, aqueles que, se acreditava, eram dotados de poder para interceder junto a Deus, uma vez que para a Igreja Católica, somente Deus pode conceder graças e realizar milagres.

$\mathrm{Na}$ era contemporânea os santos populares, como exemplo, São Benedito, foi considerado beato e declarado santo pela Igreja em virtude dos milagres realizados na época de sua vivência. Isso mostra que não foi preciso morrer por Cristo, mas teve sua total dedicação a Deus e aos homens por intermédio da fé e capacidade de realizar milagres, principalmente os da cura física e espiritual. 
Percebe-se nesse contexto que no decorrer do tempo a sacralidade que reveste uma pessoa torna-se sagrado a ponto de comprovar seu caráter transcendental, visto que a historicidade ou mesmo a vida do santo não resiste à força do mito (ELIADE, 1992).

Dessa forma, todos os santos possuem milagres fundadores, ou seja, os primeiros que serviram de suporte para a propagação de seus cultos. Esses milagres são sempre lembrados nas festas religiosas juntamente com a história de vida do santo.

As vidas dos santos constituem um importante meio de transmitir o sentido da fé cristã. Desde que o cristianismo existe, as pessoas contam e recontam as histórias dos santos. Eles têm sido homenageados em pinturas, estátuas e imagens. É importante ressaltar, que no Catolicismo a maior expressão de religiosidade encontra-se no culto a santos. A fé na intercessão junto a divindade suprema (Deus) na realização de milagres, torna-se uma das maiores características do catolicismo (WOODWARD, 1992).

Para os devotos, é por meio da promessa que se estabelece um sistema de troca com a santidade, são nas dificuldades materiais, espirituais e emocionais que a comunicação com o sagrado se intensifica na busca por graças e milagres, revelando assim em grande parte um caráter utilitário da religiosidade católica (OLIVEIRA, 1975).

O vínculo entre o santo e o devoto estabelece progressivamente uma relação de compromisso, em que deveres e direitos vão se explicitando, na forma de normas de conduta, rituais e castigos impostos a ambos os lados. Ao final desse processo, forma-se uma familiaridade entre devoto e santo, entendida não mais segundo a concepção de proximidade presente no reconhecimento inicial da santidade, mas sim, como uma proximidade própria da capacidade do santo em manifestar-se àquele que se mantém devoto de sua presença protetora.

No escopo formado pela tessitura difusa desses elementos, pode-se elaborar a seguinte concepção: a produção de santos populares corresponde, por analogia, à produção dos santos canonizados pela igreja, seguindo um processo onde aparência e função da santidade se manifestam segundo critérios biográficos (heroísmos, martírios, rompimento dos limites humanos, etc.), de proximidade e capacidade de operar milagres, resultando em familiaridade com o devoto. Tal correspondência, porém, não encontra similar por homologia, seguindo um processo em que gênese e estrutura dos critérios identificados são contraditórios, devido a manifestarem experiências, concepções e interesses distintos. 


\section{A santidade e fé no processo de burocratização da igreja}

Ser santo para a Igreja Católica significa ter atingido a perfeição cristã, o que garante ao santo um lugar de honra nos altares e um dia do ano para a veneração litúrgica, quando são lembrados durante as missas. Mas os católicos não são os únicos a cultuar santos, os budistas, os hindus, os ortodoxos, os evangélicos também os veneram $^{8}$, embora somente a Santa Sé tenha um processo formal para "fazer santos", quer por tradição, quer pelas leis canônicas.

O culto aos santos os traz de novo à vida, revigorando as lendas e dando a cada comunidade cristã um patrono celeste. Com a expansão do cristianismo, a hierarquia eclesial passou a temer que a aclamação popular pudesse incorrer em um engano. Como poderiam estar certos de que os santos estivessem ao lado de Deus?

Com relação aos mártires, os primeiros santificados, não havia grandes problemas, pois dois fatos justificavam sua elevação à condição de santo: primeiro porque as comunidades primitivas haviam testemunhado seu martírio e, em segundo, porque mais do que coragem humana "só o poder de Cristo, operando no mártir poderia sustentá-lo até o fim do sangramento" (WOODWARD, 1992, p. 60).

Daí a preocupação com os não-mártires. Como saber se os ascetas e os confessores perseveraram na fé até o fim da vida? Como saber se o santo havia morrido em perfeita sintonia com Deus, de modo a ser capaz de interceder em favor de outras pessoas?

A prova estaria, portanto, nos milagres, especialmente nas taumaturgias. Além da reputação que tinham, a fama de castidade, confessores e ascetas eram julgados merecedores de culto pelos milagres verificados postumamente em seus santuários ou por intermédio de suas relíquias 9 .

Santo Agostinho (354-430) defendia a ideia de que os milagres eram sinais do poder divino e prova da santidade dos nomes invocados para obtê-los. Para ele, o "Doutor da Igreja", considerado por muitos como o primeiro grande filósofo medieval e fundador da dogmática cristã - estudos acerca das verdades da fé - o culto santoral era de extrema importância, pois de acordo com a sua obra Cidade de Deus, o homem se encontrava diante de duas forças opostas: uma o atraia para a vida espiritual e celeste, e a outra, para a vida material e terrena. Assim, os santos exercendo a função de serem modelos para todos os cristãos, desempenhavam importante papel para a vivência dos homens no mundo terreno. 
Em todo o contexto medieval, a Igreja encorajava a veneração de relíquias como elementos de fortalecimento da fé e os papas se mostravam, geralmente, generosos em distribuir os ossos, tidos como verdadeiros tesouros espirituais, especialmente a visitantes ilustres.

No Oriente, o culto aos santos proliferou de forma diversa. Como em Constantinopla não havia mártires, a Igreja importou alguns, dando origem à prática da trasladação, a remoção de relíquias dos túmulos, geralmente acompanhados pelo desmembramento e distribuição dessas relíquias para as Igrejas de todo o mundo. Era, nesse período, senso comum que o espírito do santo estivesse presente por todo o corpo, assim, destacada, cada parte, assumia, naturalmente, poder mágico e miraculoso (WOODWARD, 1992).

Quando se tratava de reconhecer novos santos, relatos de curas miraculosas de poderes taumatúrgicos e virtudes heroicas eram os que mais pesavam. E, na jurisdição de uma diocese, a existência de um santuário importante, capaz de atrair grande número de peregrinos era de grande vantagem para o bispo local. Por isso, pode-se dizer que a história da canonização, tal como a conhecemos hoje, seja o resultado da necessidade dos bispos supervisionarem santuários e relíquias.

O regimento do culto é o regimento da fé. Assim os fiéis invocavam santos, ao se reunirem para o culto, numa espécie de chamada honorífica. Daí o sentido de canonização: incluir o nome da pessoa num cânon ou lista de bem-aventurados.

Vauchez (1987) indica que no final do período medieval, o número de pessoas contempladas com uma investigação formal começou a se estreitar, refletindo as prerrogativas do papado, pois as famílias reais piedosas e os bispos "pastoralmente" sensíveis que monopolizaram a atenção dos fiéis, já não pareciam apropriados como modelos para a Igreja universal, o que nos remete às reflexões iniciais do item anterior quando diferentes estudiosos se posicionaram pela transitoriedade do sentido de "ser santo".

A julgar pelas causas bem sucedidas, o que interessava a Roma eram candidatos cujas virtudes não pudessem ser confundidas com sucesso puramente humano.

A preferência recaiu sobre os que se dedicavam a formas radicais de pobreza, castidade e obediência - caminhos de renúncia que distinguiam a vida religiosa da vida do leigo. Muitos canonizados haviam fundado ordens religiosas ou movimentos através dos quais suas ideias pessoais se institucionalizaram e perpetuaram. 
Doravante, os avanços dos conhecimentos científicos, tanto na história, com o novo tratamento dado às fontes, quanto nas ciências médicas, reduziram significativamente o número de favores divinos aceitos como milagres. Estabeleceu-se que a contestação fosse da própria natureza dos milagres. Como norma, a Santa Sé tenta desmistificá-los até que não reste qualquer dúvida, pois uma vez reconhecido, um milagre nunca mais pode ser renegado pois a Igreja Católica não aceita, ela mesma, ser contestada em matéria de fé (VAUCHEZ, 1987).

Em 1917, as normas formais para a criação de santos foram incorporadas ao Código de Direito Canônico da Igreja, com certa reputação de precisão judiciária na descoberta e verificação de santos autênticos.

Naquela época, assim como agora, o longo processo implicava numa variedade de providências, perícias e participantes: promoção da causa, levantamento de fundos, publicidade por parte daqueles que acreditam na santidade do suposto santo, tribunais de investigação por parte dos bispos locais ou não, medidas administrativas para os funcionários da Congregação, estudos e análises dos peritos chamados a opinar, debates no tribunal entre o Promotor da Fé ou Advogado do Diabo e o advogado da causa, além de sentenças declaratórias dos cardeais conselheiros da Congregação. Mas, vale lembrar que, mesmo após ter percorrido essa longa trajetória, o aspirante a santo dependia inteiramente, como até hoje depende, do parecer papal, pois somente ele era e, continua sendo, instituído de poderes para declarar um candidato digno de beatificação ou canonização.

A seguir, com ajuda de André Vauchez (1987), vamos verificar as seguintes etapas do processo de santidade. No antigo sistema, uma causa vencedora passava pelas seguintes fases:

Fase pré-jurídica: antes de 1917, era exigido que se esperasse 50 ou mais anos após a morte do candidato para que suas virtudes fossem discutidas pelo Vaticano, a fim de se evitar que a santidade fosse fruto de uma passageira celebridade.

Com a reforma, esse período de tempo foi preterido, mas as instruções eram claras quanto aos cuidados que os bispos teriam que ter para não serem influenciados pelos meios de comunicação, sempre ávidos por modismos. Nessa fase era comum uma pessoa ou um grupo, iniciar a arrecadação de fundos para o pagamento dos trâmites do processo, o que normalmente ocorria por conta de uma ordem religiosa que além de poder arcar com essas despesas, tinha o interesse institucional para encaminhar e acompanhar o processo até a sua conclusão. 
Fase informativa: se os primeiros resultados eram julgados procedentes, o bispo local instituía o Processo Ordinário, oferecendo material para a Congregação dos Ritos que após as análises iniciais, podia ou não sugerir a abertura de um Processo Formal, em que testemunhas eram ouvidas e o candidato passava a ser designado como Servo de Deus. Visava-se nesse estágio estabelecer se havia de fato uma reputação sólida de santidade ou martírio e se os fatos arrolados sustentavam essa reputação. Ainda nesse período prevalecia a proibição de objeto ostensivo de veneração do suposto santo ${ }^{10}$.

Julgamento de Ortodoxia: cartas e outros documentos escritos pelo Servo de deus eram examinados pelos censores teológicos para julgamento da ortodoxia de seus ensinamentos e opiniões. Este estágio podia ser bastante demorado dependendo da quantidade e do teor desses escritos. Se o candidato tivesse sido ousado intelectualmente em matéria de fé, sua obra necessariamente era escrutinada com maior rigor. Um candidato a santo que tivesse divergido, de alguma forma, com os princípios tradicionais, era naturalmente recusado ${ }^{11}$.

Fase Romana: era aqui que o processo ganhava substância. O dossiê era entregue a um postulante residente em Roma, geralmente membro de alguma ordem e atuava como representante dos que haviam suscitado a causa. Este indicava ainda um advogado, leigo ou clérigo, especializado em direito canônico, e licenciado pela Santa Sé. Sua função era elaborar uma síntese que convencesse que a causa merecia ser recebida oficialmente.

Nesse estágio se travavam os debates entre o Advogado da causa e o Advogado do diabo, cuja função era apresentar objeções à candidatura, de tal forma que se o Servo de Deus resistisse a todas as investidas contrárias, o processo era finalmente aceito pela Congregação, o que podia demandar muito tempo, não raro, décadas. Depois se preparava um volume chamado positio (causa) com todo o material até então reunido, incluindo os argumentos do Promotor da Fé e do Advogado da defesa, o patrone. Após ser estudado pelos cardeais e outros prelados, funcionários da Congregação, em sessão formal no Palácio Apostólico era dada uma sentença, que se favorável, indicava fortes possibilidades de sucesso.

O Papa, nesse momento, era devidamente informado e avalia um documento, o Decreto de Introdução, que, no entanto, garantia sua aprovação administrativa, o que equivale dizer, que o processo ingressou na jurisdição da Santa Sé e, a partir de então, sua denominação era Processo Apostólico, e se constituía, numa versão mais rigorosa do Processo Ordinário. Quando estivessem esgotadas as perguntas acerca da reputação e 
ou martírio, toda a documentação era traduzida para as línguas oficiais ${ }^{12}$ : o latim, o italiano, o espanhol, o francês e o inglês, reflexo do maior número de causas de países em que essas línguas são faladas. Finalmente, a Santa Sé expedia um Decreto de Validade do Processo, garantindo sua legitimidade. Podia acontecer se surgirem novas objeções por parte do Advogado do Diabo o que exigia uma nova reunião e julgamento, agora com a presença do papa. Se a conclusão fosse de que o Servo de Deus praticou as virtudes cristãs em grau heroico ou morreu como mártir, ele ganhava o direito de ser chamado de Venerável.

Seção Histórica: criada em 1930, por Pio XI, especialmente para tratar de causas antigas e de alguns problemas que o processo judicial não tinha como resolver, como aqueles que não contavam mais com testemunhas oculares, o que exigia então uma pesquisa histórica, ou ainda julgamentos de virtudes ou martírio que dependiam muito das provas históricas.

Exame do cadáver ${ }^{13}$ : antes mesmo da beatificação, o corpo era exumado para que o bispo local fizesse a identificação. Se o cadáver não pertencesse ao Servo de Deus, o processo prosseguia, mas as orações e devoções eram proibidas, mas se o corpo não tivesse sido adulterado, aumentava o interesse pela causa, embora para a Igreja, o corpo intacto não prova a sua santidade, pois fatores ambientais, podem explicar a anomalia.

Processo de Milagres: todo o trabalho realizado até este estágio era considerado, apesar do rigor das investigações, como humano, portanto falível. Para garantir a beatificação ou canonização eram necessários os sinais divinos, os milagres ocorridos por intercessão do suposto santo. E vale lembrar que, o processo pelo qual se provava e comprova atualmente um milagre, é tão rigorosamente jurídico quanto às investigações acerca do martírio e das virtudes heroicas.

Um processo de milagre deve provar que Deus operou, de fato, um milagre geralmente uma cura física, por intercessão de um dos Servos de Deus. Como no Processo Ordinário, o bispo da diocese onde supostamente teria ocorrido o milagre, recolhia a evidência e os testemunhos, tudo devidamente autenticado em cartório. Depois, a trajetória se assemelhava a uma positio e cabia à congregação discutir, refutar ou defender as provas.

Um grupo de médicos era chamado a estudar as provas, para determinar se a cura não poderia ter ocorrido por meios naturais. Em caso negativo, o processo era entregue a teólogos consultores que, mediante provas circunstanciais, opinavam se o 
alegado milagre poderia ter ocorrido por orações ao Servo de Deus. Os casos de orações e pedidos para o Servo em discussão, juntamente a outros santos já oficiais, eram desconsiderados. Se o parecer dos consultores coincidisse com o dos cardeais, cabia ao papa certificar a aceitação do milagre.

Beatificação: antes da beatificação, o papa podia, a despeito dos méritos comprovados, determinar que ela era inoportuna ${ }^{14}$. Caso contrário o papa mandava fazer um Decreto de Beatificação e escolhia um dia para a cerimônia.

Canonização: depois da beatificação, o processo só prosseguia quando novos sinais divinos surgiam e o processo do milagre se repetia. Quando o último milagre requerido, de um total de quatro, era examinado e aceito, o papa expedia uma Bula de Canonização, declarando que o candidato deveria ser venerado como santo pela Igreja universal.

Ao canonizar alguém, a Igreja está reconhecendo a vida virtuosa deste alguém; e $a$ vida virtuosa consiste no seguimento a Jesus. Os santos e santas de Deus foram e são pessoas que se decidem por um seguimento mais radical a Cristo, pessoas que transformaram e transformam suas vidas em serviço, doação, solidariedade para com o próximo por amor a Deus; cristãos que escutaram o chamado divino ao amor exigente e responderam com generosidade e gratuidade. Este amor lança-os para a missão de anunciar ao mundo a Boa Notícia do Reino de Deus

A cerimônia solene na Basílica de São Pedro encerrava a longa trajetória, desde a preparação de santinhos para a arrecadação de fundos até a declaração do papa acerca da mensagem que o novo santo trazia para o mundo cristão. Em decorrência a todas estas exigências e da demora, às vezes por décadas, o papa Paulo VI (1963-78) nomeou uma comissão de canonistas e prelados da congregação para que estudassem um meio de simplificar e, sobretudo, atualizar tais trâmites (VAUCHEZ, 1987).

Woodward (1992) indica dois fatores para essa iniciativa: que a teologia e as ciências humanas fossem mais valorizadas no processo de exame e verificação de uma santidade e que o processo de fazer santos fosse repensado e revisto de acordo com os princípios de colegialidade do Vaticano II $^{15}$.

Durante o concílio, o cardeal belga Joseph Suennens, da ala progressista, sugeriu que o direito de beatificação fosse devolvido às conferências episcopais de cada país, visando a agilização do processo e uma ação mais diversificada e, em princípio, mais representativa dos próprios fiéis. Apesar de não receber muito apoio, a proposta do 
cardeal Suennens refletia a esperança de libertar, de certa forma, os processos santorais da burocracia vaticana.

O resultado disso foi que a comissão criada por Paulo VI avançou, pouco a pouco e, em janeiro de 1983, com o aval de João Paulo II, o sistema foi oficialmente alterado, com o anúncio da Constituição Apostólica Divinus Perfections Magister, a reforma mais significativa desde os decretos de Urbano VIII, no século XVII.

Em primeiro lugar, toda a responsabilidade de reunir provas em apoio a uma causa passava para as mãos do bispo local. E, em segundo, foram abolidos os debates entre o advogado da defesa e o Promotor da Fé - o Advogado do Diabo, doravante denominado Prelado Teólogo, e cuja função passou a ser a de escolher os consultores teológicos para cada causa, além de presidir as reuniões deste grupo (WOODWARD, 1992).

A responsabilidade de demonstrar a verdade sobre a vida e a morte de um suposto santo passou a ser do Colégio de Relatores, encarregado da elaboração de um currículo histórico-crítico da vida do candidato ${ }^{16}$, acrescido dos testemunhos de fiéis.

Tais alterações provocaram uma mudança substancial do foco: o tribunal já não era o paradigma na busca da verdade sobre a vida de um santo. As causas seriam aceitas ou rejeitadas segundo os cânones da história crítica e não pelos argumentos de adversários rivais. O relator substituiu, tanto o Advogado do Diabo como o da defesa e, preparava o relatório com as qualificações do martírio ou das virtudes enquanto cabia aos teólogos aprovar ou reprovar os documentos.

Ficava eliminado, dessa forma, o antagonismo entre aqueles já que, até então, a função do Advogado do Diabo era antagonizar o da defesa. Por vezes, uma discussão se arrastava por muitos anos, pois o Advogado pinçava uma palavra aqui outra acolá, fora de contexto, porque sua obrigação era achar alguma coisa, qualquer coisa contra a causa. Os protagonistas da Congregação para a Causa dos Santos, tal como está estruturada atualmente foram os primeiros membros da Sociedade dos Bollandistas (RODRIGO, 1988).

Em 1930, o papa Pio XI, tomando aquela associação como modelo, criou a Seção História da Congregação dos Ritos e solicitou aos bispos locais para que conduzissem as investigações, sobretudo das causas antigas, segundo os mais avançados e rigorosos critérios históricos. Entretanto, apesar da nova diretiva, o processo canônico continuava a basear-se principalmente no depoimento de testemunhas quanto à vida e os milagres do suposto santo. 
No início da década de 1980, as investigações iniciais ficaram a cargo do bispo local que, deveria consultar outros bispos da região, pois se partia do princípio de que, se a fama de um suposto santo não tivesse repercutido na vizinhança, o processo não se justificava. Desde então, os funcionários da diocese, investigam a vida, as virtudes e/ou martírio e colhem depoimentos. No entanto, não são eles que fazem a análise contextual dos acontecimentos envolvendo o candidato, já que, essa tarefa cabe a especialistas. Todos os escritos, do candidato ou, sobre ele, inéditos ou não, são avaliados a fim de garantir sua ortodoxia.

Isso significa que parte substancial do processo, antes realizado em Roma, atualmente se desenrola em âmbito local. Todavia, depois dessa fase preliminar, os dados todos são checados por órgãos competentes e só depois, o material é enviado oficialmente para o Vaticano.

Uma vez aceita a causa, a Congregação nomeia um postulante e um relator encarregado de supervisionar a redação da positio que deve conter todas as informações necessárias para que consultores e prelados possam julgar a justeza e a conveniência da beatificação ou canonização. É comum que o relator escolha um colaborador para redigir a positio, quase sempre um estudioso, da mesma diocese do santo em perspectiva. Para os casos mais complexos pode-se recorrer a colaboradores adicionais, como especialistas seculares.

Ao final dessa etapa, a positio é estudada pelos consultores, podendo, conforme o caso, ser submetida a consultores históricos. Depois, o exame é realizado por um grupo de oito teólogos. Com seis ou mais aprovações, a causa é encaminhada ao Conselho de cardeais e bispos e, somente após um parecer favorável, o processo chega às mãos do papa, que é o único poder instituído a confirmar ou não uma santidade.

WOODWARD lembra, no entanto, que nem sempre foi assim, pois,

$$
\begin{aligned}
& \text { (...) essa questão jamais ocorreu aos cristãos primitivos porque a voz da } \\
& \text { Igreja era, neste particular, a voz 'do povo'. Hoje, porém, é a voz do papa, } \\
& \text { falando em nome de uma Igreja, que determina quem a Igreja deve venerar } \\
& \text { oficialmente como santo. A regra é: o povo propõe e o papa, depois das } \\
& \text { devidas investigações, dispõe (1992, p. 36). }
\end{aligned}
$$

Romualdo Rodrigo (1988) discorda em parte desta análise e aponta que são os fiéis que têm necessidade de que a Igreja siga propondo continuamente novos modelos de santidade, capazes de ajudá-los a interpretar, em qualquer condição de sua vida, a mensagem evangélica. Por isso, continua ele, os santos não têm somente a função de 
servir de incentivo, de estímulo para os fiéis. Antes, contribuem para o fortalecimento entre a Igreja triunfante e a Igreja peregrina.

Nessa trilha, o Serge Moscovici (1990) interpreta que, os santos por terem sido homens como nós, com fraquezas, sofrimentos e imperfeições, fica mais fácil acreditar neles. A figura de Deus, criador de grandes coisas, é distante demais da realidade humana, daí a incessante busca de um intermediador.

Este parece ser o ingrediente principal para o surgimento de uma gama tão expressiva de santos, tanto os oficiais, quanto os oficiosos. Os primeiros, consagrados pela Igreja, resultam de toda a uma organização racional, enquanto os segundos são fruto de um processo puramente emocional, que se expande, apesar dos protestos e das tentativas de controle institucionais, porque para os adeptos de uma nova piedade popular, os trâmites de beatificação e canonização são inteiramente desconhecidos e, mais do que isso, totalmente dispensáveis.

A análise aponta para mais uma alternativa, além destas duas, a de Woodward (1992) e Rodrigo (1988). Acredito que, tanto os fiéis, quanto a Igreja, almejam por novos santos. Mas, enquanto os primeiros elegem espontaneamente seus santos de devoção, a Igreja defende toda uma ritualística, não só do culto, como também da comprovação dos milagres. É verdade que Roma, num passado recente, facilitou o processo santoral, mas não abriu mão do controle que exerce sobre o que considera ortodoxia: milagres e santificação.

\section{Considerações finais}

As práticas de culto a santos operam por analogias e por metáforas. Ou seja, arrasta-nos para seu interior pela força do sentido, de suas evocações e pelo forte apelo emotivo e afetivo. A lógica deste estudo não está baseada no recebimento do veredicto das certezas cientificamente relevantes, mas no desejo de ser compreendida.

As representações que, sem dúvida, se situam no âmbito do culto e devoção a santos fazem parte das crenças coletivas e valores que chegam a ter significado normativo para os homens por meio de certos rituais poderosos. Cada sociedade requer um sistema de crenças comuns que legitime as disposições sociais existentes, essas práticas e crenças gerais são inevitavelmente religiosas.

Tradicionalmente a Igreja Católica foi uma das maiores instituições responsáveis pelo trabalho de encantamento do mundo, e seus conteúdos de cultura religiosa, 
sobretudo cristãos, predominavam e demarcavam não só os sonhos das pessoas, mas também seus interditos.

As múltiplas manifestações religiosas, envolvendo a devoção aos santos constituem-se numa das mais antigas práticas do Cristianismo. Da veneração nos primeiros mártires cristãos aos nossos dias, o culto santoral sistematicamente ocupou um lugar de destaque, quer arraigado em antigas tradições, quer se renovando, se recriando para se adaptar a novos contextos, o que permite segundo Michel Vovelle (1997), apreender, por meio do estudo da longa duração, a homogeneidade, a unidade e a continuidade de ideias formadas no decorrer de sucessivas gerações.

O destaque a um determinado modelo de santidade revela uma série de manifestações, gestos e palavras, traduzindo representações coletivas, conectando um indivíduo a um determinado grupo, o que nos fornece elementos para a compreensão do termo santidade.

De modo geral, as pessoas veneram os santos e santas sem conhecer sua história e sem uma noção clara do que seja santidade. Isto é, quando questionada, a maioria responde que o santo e a santa é aquela pessoa que existe em função da intercessão, que está diante de Deus para interceder pelas necessidades materiais e espirituais do povo. Sem negar o papel da intercessão, os santos não estão em função da mesma; ou seja, a intercessão não expressa fundamentalmente o significado da comunhão dos santos. Afirmar o contrário é um equívoco comumente cometido devido à ausência de uma sólida formação que aprofunde tal realidade.

A devoção aos santos perde seu sentido quando se desconsidera este aspecto fundamental que fala do significado da santidade. Neste sentido, os santos deixam de ser meros "pedintes" de milagres junto a Deus para serem modelos de seguidores de Jesus, que inspiram outras pessoas a se colocarem no caminho da santidade.

\section{Referências bibliográficas}

BESEN, José Artulino. São Benedito. Florianópolis: Missão Jovem, 2004.

BÍBLIA SAGRADA, Edição da Família. Vozes, 49ª edição 2004.

BOUDON, Raumond. Tratado de Sociologia. Rio de Janeiro: Zahar, 1995.

BOURDIEU, Pierre. A economia das trocas simbólicas. São Paulo: Perspectiva, 2001.

BURKE, Peter. Hibridismo cultural. São Leopoldo: Unisinos, 2003. 
CERTEAU, Michel de. A invenção do cotidiano: As artes do fazer. Petrópolis: Vozes, 1994.

DURKHEIM, E. As formas elementares da vida religiosa. São Paulo: Martins Fontes, 1996.

ELIADE, Mircea. O Mito do eterno retorno. São Paulo: Mercuryo, 1992.

MACHADO, O. G. A Santidade Ontem e Hoje. São Paulo: Ed. MM, 1995.

MENEZES, Renata de Castro. "Saber pedir: a etiqueta do pedido a santos." In: Religião e Sociedade (2004): pp. 46-64.

MOSCOVICI, Serge. A máquina de fazer deuses. Rio de Janeiro: Imago, 1990.

OLIVEIRA, Pedro Ribeiro de. Catolicismo popular e mudança social. Religiosidade Popular. Suplemento. Setembro 1975, n.12, p. 3-11.

SANTOS, Boaventura de Souza. Um discurso sobre as ciências. Porto: Afrontamento, 2000.

SOARES, J. F. A Vivência do Divino na Tradição de um povo. Petrópolis: Vozes, 1986.

VAUCHEZ, André. Santidade. In: Enciclopédia Einaudi. Lisboa: Imprensa Nacional Casa da Moeda, 1987.

VELHO, Otávio. Besta fera: Recriação do mundo. Ensaio crítico de Antropologia. Rio de Janeiro: Relume Dumará, 1995.

VOVELLE, Michel. O homem do Iluminismo. Lisboa: Presença, 1997.

WOODWARD, Kenneth. A Fábrica dos Santos. São Paulo: Siciliano, 1992.

\section{Notas:}

${ }^{1}$ Para Emile Durkheim (1983) a força religiosa nada mais é do que o sentimento que a coletividade inspira a seus membros, mas projetado para fora das consciências que o experimentam. Para objetivar-se, ele se fixa em um objeto que se torna sagrado.

${ }^{2}$ Os católicos veneram a Virgem Maria, Mãe de Jesus desde os primeiros tempos do cristianismo, exemplo de um dos mais expressivos fenômenos culturais, de longa duração. O concílio de Éfeso (431) defendeu a sua maternidade divina e a reconheceu como intercessora junto ao Cristo. No Concílio Vaticano II, os bispos delegados, no Lúmen Gentium a invocaram com os títulos de Advogada, Auxiliadora, Medianeira e Protetora.

${ }^{3}$ Por isso o relato de São Lucas do martírio de Estevão (Atos dos Apóstolos, 6-7), o aponta como o primeiro mártir do cristianismo. Sua prisão, julgamento e morte, correspondem à própria trajetória do Cristo, incluindo o pedido de clemência a Deus para seus algozes.

4 A causa principal dessas sangrentas perseguições se devia ao caráter monoteísta do cristianismo e a recusa dos cristãos em reconhecer os deuses romanos e praticar o culto imperial, forma de legitimação religiosa do despotismo dos soberanos. Dessa forma, num império em que o poder tinha um caráter político-religioso, a crítica dos cristãos convertidos ao culto imperial era encarada pelas autoridades como um ato de subversão, passível, portanto, de punição. 
${ }^{5}$ DOUILLET (1960) enumera as transformações ocorridas nesse livro da Igreja Católica e esclarece que muitos santos cujos cultos não foram autorizados pela hierarquia eclesial, constam apenas dos martiriológicos particulares das dioceses ou das ordens religiosas, como um suplemento da listagem oficial.

${ }^{6}$ Cátaros ou albingenses, são hereges do sul da França, que entre os séculos XII e XIII, professavam uma doutrina dualista maniqueísta, segundo a qual o Universo foi criado e era dominado por dois princípios antagônicos e irredutíveis: Deus o (bem absoluto) e o Diabo (mal absoluto).

${ }^{7}$ Especialmente através da recitação do rosário, a forma de devoção mais popular da Igreja Católica. Trata-se de uma homenagem simbólica à Virgem Maria. De acordo com a tradição, cada Ave Maria rezada, durante a recitação, representa uma rosa oferecida a ela - daí o nome.

${ }^{8}$ Os budistas veneram seus arahants, os tibetanos os lamas, enquanto os hindus têm uma coleção de divindades encarnadas e humanas divinizadas, e destacam seus mestres espirituais, os gurus. Os muçulmanos têm os awiliya Allah, os amigos de Deus. No judaísmo não existe uma prática de encorajamento da veneração de seres vivos ou mortos, mas há uma devoção popular a figuras como Abraão ou Moisés, além de alguns rabinos, os tsaddikim, considerados justos (NIGG, 1975: 17).

${ }^{9}$ Apesar da oposição de muitos quanto à veneração das relíquias por julgarem essa uma reverência indevida, outros defenderam sua prática por entenderem que, se os corpos dos mártires eram santificados, por extensão, também eram os objetos tocados por eles (WOODWARD, 1992: 59)

${ }^{10}$ Esta determinação referia-se à determinação de Urbano VIII que proibiu o culto santoral, dos nãocanonizados oficialmente por algum papa.

${ }^{11}$ Desde 1940, o Vaticano instituiu o nihil obstat, uma espécie de salvo-conduto, uma declaração de que não existe "nada de objetável" contra o Servo de Deus nos arquivos do Vaticano, qualquer informação confidencial sobre sua obra ou o comportamento do candidato que poderia suspender definitivamente um processo (RODRIGO, 1988).

${ }^{12}$ Até o século XIX, só havia uma língua oficial para o Vaticano, o latim.

${ }^{13}$ Existe uma concepção popular de que "quando a pessoa é realmente santa o corpo não se corrompe. Esta concepção não corresponde absolutamente com a verdade, pois a conservação corporal pode ser atribuída a diversos fatores explicáveis cientificamente e que não estão necessariamente relacionados à santidade de uma pessoa" (CÂNDIDO, 1991: 71).

${ }^{14}$ Normalmente quando envolviam questões políticas.

15“‘À luz destes princípios, os bispos locais deveriam ser vistos não como simples legados do papa, mas como sucessores do colégio original de 12 apóstolos e, desse modo, co-responsáveis, juntamente com o papa, pelo governo da Igreja" (WOODWARD, 1992: 87).

${ }^{16}$ O historiador Reinaldo dos SANTOS (2000) enfatiza a importância da biografia santoral pois por meio dela é feito o reconhecimento, a divulgação e a (re) construção da memória do personagem sacralizado. Assim, a biografia se configura como uma valiosa fonte de pesquisa sobre as tramas presentes na edificação de um santo, enquadrando uma pessoa num perfil que o eleva à categoria de divindade e, portanto, de exemplo para os demais cristãos. 